Northwestern University School of Law Northwestern University School of Law Scholarly Commons

Faculty Working Papers

2008

\title{
The Mismatch Between Public Nuisance Law and Global Warming
}

David A. Dana

Northwestern University School of Law, d-dana@law.northwestern.edu

\section{Repository Citation}

Dana, David A., "The Mismatch Between Public Nuisance Law and Global Warming" (2008). Faculty Working Papers. Paper 151. http://scholarlycommons.law.northwestern.edu/facultyworkingpapers/151 


\title{
THE MISMATCH BETWEEN PUBLIC NUISANCE LAW AND GLOBAL WARMING
}

\author{
David A. Dana*
}

\section{INTRODUCTION}

Public nuisance - so long a dreary common law doctrine that law students rush by in a Property course their first year and then forget - is making a big comeback as state Attorney Generals use the doctrine to tackle truly enormous social problems. Most notably, perhaps, are the global warming lawsuits. In the global warming lawsuits brought by state Attorney Generals (AGs), the alleged public nuisance is global warming itself, and the relief sought is reductions in the greenhouse gas emissions from gigantic power plants and damages from automakers to fund state efforts to mitigate or address global warming. ${ }^{1}$ Private plaintiffs have also brought global warming public nuisance suits, ${ }^{2}$ seeking less sweeping (but still substantial) relief, including, most recently, the relocation of an Alaskan Inuit village that is sinking into the sea as the ice thins. ${ }^{3}$ These lawsuits seek to use public nuisance to redress what is unquestionably the biggest environmental challenge this country or world has ever faced. What is being stacked on the shoulder of poor "public nuisance" in these suits is nothing less than staggering.

The federal judges in the global warming lawsuits have simply said no to the burden of tackling a massive environmental challenge to the nation and planet under the rubric of public nuisance. They have held that the suits implicate the so-called "political

\footnotetext{
* Professor of Law and Associate Dean for Faculty Research, Northwestern University School of Law. I am very grateful for the support of the Searle Foundation and for the very helpful comments I received from Jonathan Adler, Henry Butler, Rob Glicksman, Tom Merrill, [add others].

${ }^{1}$ The dismissal of the power plant and automaker suits are currently under appeal to the Second and Ninths Circuits, respectively. See Connecticut v. Amer. Elec. Power Co., Inc., 406 F. Supp. 265 (SDNY 2005) (dismissing complaint); Order Granting Defendants' Motion to Dismiss, People of the State of California v. General Motors, No. C06-05755MJJ, 9/17/2007 [California Order].

${ }^{2}$ See Korsinsky v. EPA, 192 F’App’x 171 (2006) (dismissing complaint alleging damages from greenhouse gas emissions from New York and New York City); Comper v. Murphy Oil Co et al, No. 05-CV-436L Q (SD Miss Aug. 30, 2007) (dismissing gulf coast property owners' public nuisance suit against petrochemical companies for damages to their homes for storms that are attributable to global warming). The Comper case is currently under appeal in the Fifth Circuit.

${ }^{3}$ See Native Village of Kivalina v. Exxon Mobil Corporation et al (CV 08-1138) (N D Cal filed 2/26/2008) (complaint by village residents alleging that global warming is melting the ice that supports the village and seeking \$400 million from 20 major companies to pay for the cost of relocating the village). See also Felicity Barringer, Flooded Village Files Suit, Citing Corporate Link to Climate Change, NY TIMES, Feb. 27, 2008.
} 
question” doctrine or are otherwise jurisdictionally defective. ${ }^{4}$ The political question doctrine holdings, logically, would seem to mean that the federal courts will and must stay out of the business of global warming even if Congress and the Executive take no additional actions action to address global warming. The political question doctrine, so applied, simply removes the courts and the common law from the picture. ${ }^{5}$

Is this the "right" result? That question is worth asking for several reasons. First, thoughtful commentators suggest that the common law courts should play a role in climate change. ${ }^{6}$ Second, the courts have not decisively ruled that these commentators are wrong. Even if all three of the federal appeals courts currently involved (the Second, Fifth and Ninth Circuits) affirm the dismissal of federal common law claims predicated on the theory that global warming is a public nuisance, plaintiffs could still sue in any number of state courts alleging a public nuisance under state law. ${ }^{7}$ The scope, high stakes, and long-term-nature of the climate change problem means that we may well observe a second or third or fourth wave of lawsuits alleging that global warming is a public nuisance. ${ }^{8}$

\footnotetext{
${ }^{4}$ In the private plaintiff cases decided to date, the court have dismissed the suits both on lack of standing and political question grounds. Standing was briefed and argued in the State Attorney General cases, but the courts in those cases declined to reach that issue.

${ }^{5}$ As far as I can discern, there is no case law in which a court has decided that an issue previously deemed a "political question" had become a justiciable question due to changed factual circumstances. The use of the political question doctrine is thus problematic if for no other reason than it seems to remove from the courts the practical option of re-entering an arena if there are dramatic changes in the factual circumstances.
}

${ }^{6}$ See, e.g., Jason Czarnezki \& Mark l. Thomsen, Advancing the Rebirth of Environmental Common Law, 34 BC ENVT AFF L REV 1, 2-4, 14-18 (2007) (addressing the merits of the common law public nuisance suits and suggesting such suits may serve a useful function); Kirsten H. Engel, Harmonizing Regulatory and Litigation Approaches to Climate Change, 155 U PA L REV 1563 (2007) (arguing that "state-initiated climate change litigation fills a niche created by the need to address this global problem in the absence of federal action.”); David A. Grossman, Warming Up to a Not-So-Radical Idea: Tort-Based Climate Change Litigation, 28 COLUM J ENVTL L 1 (2003) (endorsing the use of public nuisance to address global warming). For a good analytic analysis of some of the legal issues presented by characterizing global warming as a public nuisance, see Thomas W. Merrill, Global Warming as a Public Nuisance, 30 COLUM J ENVT L 293 (2005).

${ }^{7}$ The United States Supreme Court recognized that cases characterized as transboundary pollution cases may be brought under the state nuisance law of the polluter's state even if federal statutory law has displaced federal common law nuisance actions. See International Paper Co. v. Ouellette, 479 US 481 (1987). International Paper could be used by California and other states to (for example) sue General Motors in California but under the Michigan common law of public nuisance. For a general argument for the continuing vitality of the common law in an age of federal and state regulation, see Alexandra Klass, Common Law and Federalism in the Age of the Regulatory State, 92 IOWA 545 L REV (2007).

${ }^{8}$ It is also possible that advocates will seek to extend the public nuisance paradigm to transnational disputes over greenhouse gas emissions before international tribunals. Already, the Inuit leaders who have brought a public nuisance suit in California have announced that they will file a petition with the Organization of American States. Inuit say global warming violates their human rights, Arctic inhabits plan to file a complaint with the Organization of American States, 6/12/2005, available on cnn.com. One could also imagine that individuals or communities harmed by global warming outside the United States would seek 
This Article rejects the claim that common law courts are appropriate institutions to address the problem of climate change by regulating greenhouse gas emissions, and argues that, instead, the states should be limited to using state legislation to serve the purpose of prodding more meaningful consideration of global warming by the federal political branches. Proponents of "free market environmentalism" generally have advocated the re-direction of environmental issues from the realm of statute and regulation to the realm of common law, and have been fans of judge-made nuisance law as a means to resolve complaints by those who believe themselves to have been unreasonably victimized by pollution. ${ }^{9}$ Global warming, however, is not best conceived as a binary pollution dispute between producers and recipients of "pollution"; rather, global warming is an issue of how to manage a common natural resource (the atmosphere) so that the human "load" on the resource is or will not push the resource beyond a "tipping point" it is generally understood we (human kind) should not want to reach. As a commons issue, global warming raises difficult (scientific and philosophical) meta-questions of what load is amenable with human flourishing and difficult distributive and economic efficiency issues as to how much weight on the resource all the users and potential future users should be allowed to place. Private and public nuisance cases have not been used to manage the load over time on common natural resources, and for good reason: courts are not well-equipped to generate and implement long-term resource management plans. By understanding global warming as a commons resource management problem, we can better understand why the courts are not the best institutions for resolution of disputes over global warming. Judicial reliance on a costbenefit-analysis or reciprocity-Golden-Rule approach - two approaches that have been suggested by leading legal academics -- would not make climate change any more tractable an issue for the courts.

The Article begins with an account of the law of public nuisance and the global warming public nuisance claims and decisions to date. I argue that the courts' reliance on the political question doctrine as a ground for dismissal of these claims is unsatisfactory because the courts do not adequately explain why global warming is a political question any more than the many other questions the courts have deemed justiciable. Instead of the political question doctrine, the courts could make use of two more conceptually coherent grounds for dismissal -- lack of standing and lack of causation.

A more fundamental question, however, is whether, as a normative matter, courts should dismiss these suits. Part II explores why courts in their common law-role are not

to bring suit within the United States under the Foreign Alien Tort Claims Act, 28 USC 1346(b), 2671 et seq.

${ }^{9}$ See, e.g., Terry L. Anderson, Enviro-Capitalism vs. Enviro-socialism, KAN J L \& PUB POLICY, Winter 1995, at 38 (advocating "more reliance on the private law of torts and contracts"); Roger E. Meiners \& Bruce Yandle, Clean Water Legislation: Reauthorize or Repeal?, in TAKING THE ENVIRONMENT SERIOUSLY 73, 75, 94-95 (Roger E. Meiners \& Bruce Yandle, eds, 1993) (calling for the use of common law nuisance suits to replace statutory schemes of pollution control). See also Eric Biber, A House with a View, 109 YALE L J 849, 856 n 37 (2000) (arguing that "free market environmentalists [ ] tend to be extremely hostile to government regulation and see the use of nuisance and takings law as a replacement for, rather than a supplement to, the current statutory schemes.”). 
the first-best or ideal institutions to address the allocation-of-property-rights-in-thecommons issues inherently implicated by the public nuisance claims. This a task that the federal political branches, the federal Executive and Congress, are best suited to address.

But what if those federal political branches, due to some kind of failure of or distortion in the federal political process, avoid serious consideration of the problem of global warming? Should not the states - and in particular the coastal states at greatest risk from global warming - be able to do something to prod consideration by the federal political branches? This Article argues that, on democratic legitimacy and accountability grounds, state legislation is strongly preferable to common law public nuisance suits as a means that a state or states could use to prompt action by the federal political branches. Consequently, the courts should dismiss common law public nuisance suits regarding global warming on standing or causation grounds, but at the same time they also should also err on the side of upholding state global warming legislation. Specifically, they should employ a heightened ripeness requirement for federal preemption challenges and a robust presumption against federal preemption once the preemption challenge is deemed ripe. And they should avoid turning the dormant commerce clause doctrine into a vehicle for second-guessing state legislation that is facially neutral with respect to in-state and out-of-state producers.

\section{PUBLIC NUISANCE AND THE GLOBAL WARMING LITIGATION}

The Restatement defines "[a] public nuisance as an unreasonable interference with a right to the common to the general public." ${ }^{10}$ Traditionally, the public rights at issue in public nuisance litigation were public rights to be free of criminal violations or what were seen to be gross offenses to public morality (as in places of prostitution). ${ }^{11}$ The category of public nuisance - like the category of nuisance generally - also has long been thought to include rights to be free from physical harms from pollution that crosses or could cross property boundaries. Importantly, however, public nuisance - like nuisance generally - only speaks to unreasonable interferences. Unreasonableness of a use may depend on first in time (i.e., which came first, the polluters or the polluted) and what is a customary use in the relevant area. Unreasonableness of a use also may depend on an utilitarian balancing of the social benefits of the interfering use and the social costs it imposes on the public. ${ }^{12}$ In truth, once de-linked from a criminal or other statutory violation, a wide range of behavior could or could not be deemed a unreasonable and

\footnotetext{
${ }^{10}$ See Restatement (Second) of Torts Sec. 821B (1)(1979).

${ }^{11}$ For a good historical account, see Victor E. Schwartz \& Phil Goldberg, The Law of Public Nuisance: Maintaining Rational Boundaries on a Rational Tort, 45 WASBURN L J 541 (2006).

${ }^{12}$ See Jesse Dukeminier et al, PROPERTY ( $6^{\text {th }}$ ed.), at 661 (explaining that "the underlying bases for liability for public nuisance are the same as those for private nuisance - there must be a substantial harm caused by intentional and unreasonable conduct or by conduct that is negligent, reckless, or abnormally dangerous. And, as with private nuisance, unreasonableness turns heavily on considerations of gravity and utility.”). For a good overview of the doctrinal elements public nuisance, see Denise E. Antolini \& Clifford L. Rechtschaffen, Common Law Remedies, in Denise E. Antolini \& Clifford L. Rechtschaffen, eds, CREATIVE COMMON LAW REMEDIES 18-30 (ELI 20007).
} 
hence a common law public nuisance. Public nuisance, in a sense, is a legal doctrine that invests in the courts the task of social planner, and as such it seems to invest in courts tasks that one might think would belong more appropriately in the legislative arena. ${ }^{13}$

There is an open question as to what relief may be appropriate when a court finds a public nuisance. Traditionally, public nuisance litigation was about abatement or other injunctive relief, not damages and certainly not damages primarily or exclusively. It is therefore not clear whether a public nuisance suit explicitly or de facto for damages is permissible under federal or state common law. ${ }^{14}$

Public nuisance litigation traditionally has been brought by state officials, and in particular state AGs on behalf of their states. Private persons, however, are permitted to bring public nuisance claim provided that they have suffered some "special injury" apart from the injury suffered by the public as a result of the alleged interference with a public right. ${ }^{15}$ Both public (state) and private plaintiffs must establish the basic requirements of standing, such as injury in fact and redressability. At least after the United States Supreme Court's decision in Massachusetts v. EPA, however, it seems clear that states and state AGS are held to a lower or relaxed standard of proof with respect to these basic requirements. ${ }^{16}$

\footnotetext{
${ }^{13}$ As Justice Blackmun candidly explained in Lucas, “[o]nce one abandons the level of generality of [do not harm others] , . . one searches in vain, I think, for anything resembling a principle in the common law of nuisance.”). Lucas v. South Carolina Coastal Council, 505 US 1033, 1055 (1992) (Blackmun, J., dissenting).

${ }^{14}$ For an argument that common law public nuisance does not cover damages relief, Richard O. Faulk \& John S. Gray, Alchemy in the Courtroom? The Transmutation of Public Nuisance Litigation, $2007 \mathrm{MICH}$ STATE L REV 941, 950. But see Evansville v. Kentucky Liquid Recycling, 604 F.2d 1008, 1019 (7 ${ }^{\text {th }}$ Cir. 1979) (holding that "a request for damages does not preclude the exercise of jurisdiction of a claim arising under the federal common law of interstate pollution”).

${ }^{15}$ See William H. Rodgers, Jr., ENVIRONMENTAL LAW (West), Sec. 2:2, Public Nuisance - Classical Expression (2007); see generally Denise L. Antolini, Modernizing Public Nuisance Law: Solving the Paradox of the Special Injury Rule, 28 ECOLOGY L Q 755, 826 (2001).

${ }^{16}$ In Massachusetts v. EPA, 127 S Ct 1438 (2007), the majority rooted this differential standing threshold in case law such as Georgia v. Tennessee Copper, 206 U.S. 230 (1907), which the majority read as giving each state quasi-sovereign rights not enjoyed by non-state plaintiffs. See id. at 1454 (explaining that "[j] ust as Georgia’s ‘independent interest . . . in all the earth and air within its domain’ supported federal jurisdiction a century ago, so too does Massachusetts' well-founded desire to protect its citizens from air pollution originating outside its border.”). In dissent, Justice Roberts argued that "[r]elaxing Article III standing requirements because asserted injuries are pressed by a State . . . has no basis in our jurisprudence ...”Id. at 1464. Justice Roberts may be right that Tennessee Copper did not establish any special standard for States regarding standing: injury-in-fact and redressability would seem to have been readily met in that case, both because the State owned property and because the State could fairly be understood to be representing the injured farmers in Georgia. In Tennessee Copper, there was no question the farmers had in fact been injured and that their injuries were redressable by court order. Moreover, the majority opinion in Massachusetts v EPA does not develop and explanation of why due regard for States as States should translate into lower thresholds for showings of injury in fact or redressability.
} 
In 2004, the AGs of eight states (Connecticut, New York, California, Iowa, New jersey, Rhode island, Vermont, ad Wisconsin) and the Corporation Counsel for the City of New York sued four major power companies and the Tennessee Valley Authority under federal common law and state law, seeking an order requiring the defendants to abate their contributions to the public nuisance of global warming. The complaint alleged that the defendants were the five largest emitters of carbon dioxide in the nation, and their emissions constituted approximately one quarter of the total emissions from the U.S. electric sector. ${ }^{17}$ The complaint did not propose specific abatement targets. Except for Wisconsin, none of the five defendants were incorporated in or had major facilities in any of the plaintiff States. ${ }^{18}$

In 2006, the California AG sued six major automobile manufacturers, alleging that they had created a public nuisance under federal common law and California state law by producing and selling vehicles in the United States that had contributed to global warming by virtue of their emission of carbon dioxide. According to the complaint, the automakers had produced vehicles that emitted over 289 metric tons of carbon dioxide or over twenty percent of the carbon dioxide emissions in the United States. ${ }^{19}$ California requested monetary damages, attorney's fees, and a declaratory judgment for future monetary expenses incurred by the State of California in connection with the nuisance of global warming. Notably, none of the defendant automobile manufacturers is a corporation incorporated or with headquarters in California.

The power plant and automobile suits - indeed any public nuisance suit predicated on climate change - could be challenged on a variety of legal theories. I think it is helpful to distinguish the possible theories in terms of how much they require or allow the court to engage in a meaningful inquiry into the problem of climate change and the specific allegations regarding greenhouse gas emissions and climate change. On one end of the spectrum, the non-engagement end, the courts could dismiss the nuisance suits as nonjusticiable on the grounds that the plaintiffs lack standing or (even if they do) the issues implicated by the claims are "political questions" and hence nonjusticiable. If the court determines that the plaintiffs have standing and the case is justiciable, then it could still dismiss the case on the grounds that the federal common law in the arena of global warming had been displaced by federal statutory law. If the court determines the federal common law is not displaced, then the court could dismiss still the complaint for failure to state valid claims under the federal common law of nuisance. If the courts hold that the complaint alleges the necessary elements of nuisance, it could oversee the discovery

\footnotetext{
${ }^{17}$ Complaint, Connecticut et al v. American Power et al, at 26, available at www.cleancarscampaign.org..

${ }^{18}$ This is a point the defendants emphasized, apparently in an effort to portray the litigation as an unfair attach on out-of-state and hence unrepresented interests. See Memorandum of Law in Support of the Motion to Dismiss of the Southern Co. et al for Lack of Personal Jurisdiction, Sept. 30, 2004, 2004 WL 254466, at 8 (explaining that the power plant suit "conspicuously do[es] not include a single plant in New York or in any other plaintiff state with the exception of Wisconsin").

${ }^{19}$ Complaint for Damages and Injunctive Relief, California v General Motors Corp et al, at 9, available at http//ag.ca/gov.
} 
process and then conclude that there was no material issue of fact and that the plaintiffs clearly could not made the factually showings they needed to make. Finally, on the opposite end of the spectrum, the full engagement spectrum, the court could conduct a trial on the nuisance claim and reach (with or without a jury) a judgment on the merits at the end of the trial. At each point on the spectrum, the bottom line result may be the same - the defendants win - but the length of litigation, the extent of pleading and any discovery, and the nature of the court analysis will differ. ${ }^{20}$

Both the power plant and automaker public nuisance suits brought by state AGs were dismissed by the courts at the least engagement point in the spectrum described above - at the point of the initial determination of justiciability. The district court in both cases dismissed the suits as nonjusticiable on political questions grounds, thereby avoiding the additional inquiry that might be necessary to determine whether the claims were displaced by federal statutory law or failed to include necessary elements of common law federal or state nuisance or were simply unsupported by the necessary facts..

The district court in both cases cited the six situations for finding political question nonjusticiability that the Supreme Court articulated in Baker v. Carr, ${ }^{21}$ and reaffirmed in Vieth $v$. Jubelirer, ${ }^{22}$ and then relied upon the first three in finding the public nuisance claims nonjusticiable. These three situations are "[1] a textually demonstrable constitutional commitment of the issue to a coordinate political department; or [2] or a lack of judicially discoverable and manageable standards for resolving it; or [3] the impossibility of deciding without an initial policy determination of a kind clearly for nonjudicial discretion ...."23 It is the third factor that the district court in both the power plant and automaker cases heavily relied. ${ }^{24}$

In both the power plant and automaker cases, the district court emphasized the incredible scope and difficulty of the issue of climate change. For example, the court in the power plant case recited a host of policy choices raised by the suit that the defendants had cited in seeking dismissal, including whether the power industry or its consumers should bear the costs of emission reductions, whether the costs of abatement should be spread throughout the power industry and/or extended to other industries, what the economic implications of abatement would be, and what the implications would be for the nation's energy independence, and by extension, it national security. ${ }^{25}$ And in both

\footnotetext{
${ }^{20}$ See generally Benjamin P. Harper, Climate Change Litgation: The Federal Common Law of Interstate Nuisance and Federalism Concerns, 40 GEORGIA L REV 661 (2006) (reviewing a range of legal problems the AG power plant suit faces).

${ }^{21} 369$ U.S. 186 (1962).

${ }^{22} 541$ U.S. 267 (2004).

${ }^{23}$ Vieth, 541 U.S. at 277-78.

${ }^{24}$ See American Electric Power, 406 F. Supp. at 273; California Order, at 8.

${ }^{25} 406$ F.Supp. at 273.
} 
cases the court emphasized that the federal government had specifically not spoken to not answered -- these and other "initial policy determination[s] that must be made before a non-elected court can properly adjudicate a global warming nuisance claim . . .." 26

According to the district courts, Congress and the federal Executive, through a "specific refusal to impose [ ] limits on carbon dioxide emissions" - through inaction as to climate change - had made public nuisance suits nonjusticiable under the third Baker situation for political question nonjusticiability: "Because resolution of the issues presented requires identification and balancing of economic, environmental, foreign policy, and national security interests," "'an initial policy determination of a kind clearly for non-judicial discretion"” is required." 27 In the automaker case, California argued that such policy judgment need not be made because the suits sought not abatement but damages. The court found this to be an irrelevant difference between the power plant and automaker suits because "regardless of the relief sought, this Court is left to make an initial decision as to what is unreasonable in the context of carbon dioxide emissions." 28 The court explained that "[s]uch an exercise would require the Court to create a quotient or standard in order to quantify the potential damages that flow from Defendants' alleged act of contributing thirty percent of California's carbon dioxide emissions.”29

The courts' political question analysis is problematic. For one thing, the Supreme Court has suggested that the Baker factors are listed in descending order of importance. ${ }^{30}$ The first factor -- a textually demonstrable constitutional commitment of the issue to a coordinate political department - would limit political question cases to ones where the constitution itself indicated that the issue belonged exclusively within the jurisdiction of the Executive or Congress. And indeed, both liberal and conservative legal commentators alike have been deeply troubled by the notion that the courts could avoid their constitutional responsibility to hear cases brought to them in the absence of any constitutional text that removes those cases from their presumptive jurisdiction as courts of law. ${ }^{31}$ There is not a serious argument that specific constitutional text commits the

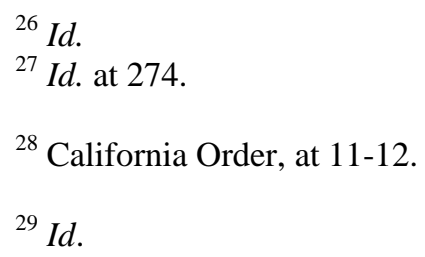
descending order of importance"). Although the language in Vieth is contained only in a plurality opinion, it has been favorably cited (if perhaps not necessarily actually followed) by the lower federal courts. See, e.g. Alperin v. Vatican Bank, 410 F3d 532, 545-46 ( $9^{\text {th }}$ Cir. 2005); El-Shifra Pharmaceuticals Co. v. United States, 378 F3d 1346, 1361 (Fed Cir 2004); Barasich v. Columbia Transportation Co., 467 F Supp 676, 680 (E D La 2006).

${ }^{31}$ See, e.g., Louis Henkin, Is There a 'Political Question' Doctrine?, 85 YALE L J 597, 598-99 (1976) (arguing that there is no basis for political question abstention absent a specific constitutional provision reserving the question to the authority of Congress or the Executive); Jack L. Goldsmith, The New Formalism in United States Foreign Relations Law, 70 U COL L REV 139, 1410 (2005) (arguing that 
issue of global warming common law to the exclusive jurisdiction of the Executive or Congress. Massachusetts v EPA stands as dramatic support for the proposition that the courts do indeed have a role vis-a-vis global warming.

Moreover, the Baker test aside, it is hard to see how global warming is a more "political" issue in the regular senses of the word than others the federal courts have found justiciable. Tocqueville famously remarked that all important issues in America find their way into the courts, and that claim may be even stronger now than when it was made. ${ }^{32}$ The United States Supreme Court has recently heard cases regarding everything from abortion to affirmative action to federal congressional districting to who won or will win the Presidential election. ${ }^{33}$ Because the courts do hear cases that seem to involve issues that are the subject of intense political controversy and political consequence, there would seem to have to be some showing that global warming is especially or differently political in order to justify a holding that the issue is nonjusticiable. ${ }^{34}$ The courts in the power plant and automaker cases certainly did not try to make such a showing.

But if their aim is to dispose of global warming public nuisance suits with no or relatively little discovery, courts need not employ the political question doctrine. With respect to non-state, private plaintiffs, courts have and can use lack of standing to achieve that purpose. For public nuisance standing, as noted, a plaintiff must show special injury, and indeed a special injury that is concrete and redressable by the court. Because climate change has or will have at once broad-based and highly uncertain effects and any relief ordered with respect to any set of defendants will have uncertain effects and hence not meet the redressability threshold, a private plaintiff cannot establish standing. By contrast, with respect to state AG plaintiffs, a dismissal for lack of standing cannot be readily justified: if Massachusetts can establish standing to challenge the failure of the EPA to regulate greenhouse gas emissions, as it did in Massachusetts v EPA, there would seem to be no reason Massachusetts could not establish standing to challenge greenhouse gas emissions as part of a public nuisance of global warming. And indeed neither the court in the power plant or the automaker case relied on standing in dismissing the suit.

With respect to State AG public nuisance suits, however, the courts could dismiss the suits on the substantive ground that the plaintiffs cannot show that the defendants'

political question abstention reflects judge's imposition of their own personal values, rather than fidelity to a neutral principle).

${ }^{32}$ See Mark A. Graber, Resolving Political Questions into Judicial Questions: Tocqueville's Thesis Revisited, 21 CONST. COMMENT. 485 (2004) (quoting Tocqueville as asserting "[s]carcely any political question arises in the United States that is not resolved, sooner or later, into a judicial question.”).

${ }^{33}$ See Bush v. Gore, 531 U.S. 98, 158 (2000) (Breyer, J., dissenting) (arguing that the Court should have abstained from addressing the "highly politicized matter" of the counting of ballots in a contested election).

${ }^{34}$ But see Graham O’Donoghue, Precatory Executive Statements and Permissible Judicial Responses in the Context of Holocaust Claims Litigation, 106 COLUM L REV 1119, 1152 (2006) (noting that the vagueness of the term "political question" and the doctrine does give courts "room to maneuver," and explaining that federal courts have held that Holocaust-related claims are nonjusticiable despite the absence of constitutional text that would clearly relegate such claims to the exclusive jurisdiction of the political branches). 
greenhouse gas emissions caused the harms to the state, and hence cannot satisfy the causation element of the nuisance cause of action. Unless the suit brings in all the major greenhouse gas emitters in the world, it will be impossible for the plaintiff to show (or even really allege) that it is more likely than not that the defendants' emissions, and in of themselves, caused the warming that allegedly caused or will cause the harm to the state. $^{35}$ Greenhouse gas emissions, individually, do not translate into warming or indeed any identifiable harm at all. Moreover, it will be impossible to show that the defendants' emissions were even part of the total emissions that caused the alleged harm, since even in the absence of the defendants' emissions, it will be plausible to suppose that the same degree of warming would have occurred or will occur. Thus, state AGs, even if they do have standing, cannot not meet the causation requirement, a requirement that the Supreme Court has not yet held to be lower or less demanding for State plaintiffs than non-State ones. ${ }^{36}$

The California AG in the automaker suit argues that joint and several liability is the appropriate standard for public nuisance cases. However, joint and several liability has generally been applied where each party's actions independently caused an undivided harm, or where the contributing party acted implicitly or explicitly in some kind of concert with the other contributors to the harm. There is language in a Restatement comment suggesting an unusually broad conception of joint and several liability in the context environmental public nuisance ${ }^{37}$ but that is slim authority on which to set aside the enormous problems of allocating causal responsibility for global warming in the context of a public nuisance suit against actors that, by the plaintiff's admission, account for only a fraction of historical or even recent greenhouse gas emissions.

Courts, however, sometimes do set stretch traditional tort requirements of causation, ${ }^{38}$ and so one could imagine a court at least taking seriously the idea of doing so in the context of global warming public nuisance suits. Fidelity to legal tradition and

\footnotetext{
${ }^{35}$ Although using the rubric of standing as a basis for granting the defendants' motion to dismiss, the federal district court in Comper used language that could have readily justified dismissal on lack of causation grounds. See Peter Glaser \& Lynne Rhode, Three Federal Courts Reject Public Nuisance as Climate Change Control, WLF Legal Opinion Letter, Vol 17, No 24, available at www.wlf.org (quoting the judge in Comper as stating orally that dismissal was proper because plaintiffs' injuries are not "traceable to the individual defendants but is instead . . . attributable to a larger group that are not before this Court ... . “).

${ }^{36}$ Even the trial court in the Rhode Island lead paint case - a court that adopted an expansive conception of public nuisance - charged the jury that the plaintiff needs to show that a defendant substantially contributed to the creation of the public nuisance that is harming the public. See Faulk \& Gray, supra note [ ], at 987.

${ }^{37}$ See Restatement (Second) Torts Sec. 840 E cmt. B (1979) (explaining that “[i]t may . . . be unreasonable to pollute a stream to only a slight extent, harmless in itself, when the defendant knows that pollution by others is approaching or has reached the point where it causes or threatens serious interference with the rights of those who use the water ...”).

${ }^{38}$ See, e.g., In re Methyl Tertiary Butyl Ether Products Liability Litigation, 447 F. Supp. 289, 304-305 (SDNY 2006) (holding that in a suit against multiple gasoline market defendants, plaintiff could proceed on theories of alternative liability, including market share and commingled product liability).
} 
principles of justice aside, the courts should not do so in the global warming public nuisance context because courts quite simply are not competent to tackle the problem of global warming. It is to that argument to which we now turn.

\section{THE LIMITS OF THE COURTS IN MANAGING THE ATMOSPHERIC COMMONS}

The courts using the common law are not the first-best institutions to resolve localized binary pollution disputes across state borders. In the arena of interstate water issues, the United States Supreme Court has strongly signaled that this is or should be in an arena for the legislature, rather than the courts employing the common law. ${ }^{39}$ But there is some precedent of courts addressing such localized binary pollution disputes using common law, including, in the arena of air pollution, Georgia v. Tennessee Copper Co. $^{40}$

In that case, sulphur dioxide air pollution from copper smelters in Tennessee deposited in Georgia, causing property damage to farms and forests in Georgia. The pollution in question was (the parties and Court assumed) caused by the Tennessee facilities and borne by the Georgia property owners and the State of Georgia, so that the dispute amounted to whether Georgia residents had a right not to bear the cost of Tennessee pollution. The injunction entered in Tennessee Copper in fact resulted in meaningful pollution reductions without shutting down the smelters, and can be cited in support of the proposition that courts through common law case adjudication are good at developing localized solutions for localized (albeit interstate) problems. And indeed California's AG relied heavily on Tennessee Copper in the automaker public nuisance suit. According to the AG, "[a] the State of Georgia did one hundred years ago in Tennessee Copper, California makes a fair and reasonable demand, here that the Automakers be held liable in nuisance for the substantial harm they have caused and are causing to California's quasi-sovereign interests." ${ }^{41}$

However, climate change - even climate change as a problem within US borders, ignoring the world outside the United States - is not best conceptualized as an interstate pollution dispute where an upwater or upwind state exports pollution to a downwater or downwind state. In that sort of case, the question for a court to resolve is whether that export should be treated as an actionable wrong. Rather, climate change is best conceptualized as an overexploitation-of-a-commons problem, as a commons resource management problem in the face of the well-known dynamics of the tragedy of the

\footnotetext{
${ }^{39}$ See City of Milwaukee v. Illinois and Michigan, 451 U.S. 304 (1981) (holding that the federal Clean Water Act displaces the federal common law of nuisance vis-à-vis interstate water pollution). The courts in the power plant and automaker cases did not reach the question whether federal statutory law had similarly displaced the federal common law of nuisance vis-à-vis interstate air pollution generally or greenhouse gas emissions (understood to be a particular kind of air pollution).

${ }^{40} 206$ U.S. 230 (1907).

${ }^{41}$ Appellant's Opening Brief, California v. General Motors Corp. et al, in the United States Court of Appeals for the Ninth Circuit, Case No. 07-16908, at 12.
} 
commons. And public nuisance law has never been touted as, or served to effectively address, the tragedy of the commons. Conservative, free market environmentalist commentators have touted both the use of public nuisance as a means to decide localized pollution disputes and the assignment of property rights in natural resources to redress the tragedy of the commons. ${ }^{42}$ But they have not (and rightly so) argued that public nuisance law has or should be used to assign property rights in commons resources as a way to redress the tragedy of the commons. Rather, they have (properly) assumed or argued that the initial property rights assignment in a commons is a quintessentially political, and hence legislative, task.

A simple thought experiment may help illuminate my point about climate change as tragedy of the commons. Imagine a large fishery with hundreds and thousands of competing fishing operations spread over hundreds of miles of coastline. The fishing operations each have a port from which they launch, but they can and do fish throughout the entire area of the fishery. The main stock in the fishery - say, the cod - is being overfished and yields are dropping. Many believe that the fishery faces a tipping point where even if the overfishing does not increase further, the fish stock could fail to successfully reproduce and disappear altogether. Some fishing operations on the northern coastline sue fishing operations based one the southern coastline, alleging that the defendants' harvesting of large numbers of fish is a public nuisance that should be abated, on the theory that the overfishing may lead to the public harm of the failure of the fishing stock to reproduce.

Almost anyone would say that this would not be a dispute that the courts acting under the common law would be well positioned to decide. For one thing, an assessment of what is a sustainable yield or fishing catch is a highly difficult question that requires continual updating, inasmuch as it implicates how a species population will fare over time, given a range of environmental factors that may fluctuate and not be well understood. It is also a philosophically difficult question, as it implicates what the goals of sustainability should be - maintaining the fish population at constant levels even at the cost of imposing hardship on many fishing operations, attempting to prevent a tipping point to depletion/extinction through fishing limits but allowing for further population reductions, or just allowing depletion to happen with the goal and understanding that other stocks or farmed fishing can take up the excess consumer demand. A difficult question embedded in these choices is whether preservation of the fishing stock is or should be an economic goal only or also an environmental/preservationist goal in itself. Even if the court could resolve these normative questions, the court would somehow have to arrive at a decision as to how to allocate rights to the yield as among current users, and to grapple with the question of what to reserve for possible new users. ${ }^{43}$ And it is unclear

\footnotetext{
${ }^{42}$ For the most comprehensive statement of free market environmentalism, see Terry L. Anderson \& Donald R. Leal, FREE MARKET ENVIRONMENTALISM (1991).

${ }^{43}$ For a discussion of why the allocation of property rights in fisheries is so difficult and often not accomplished despite the broad consensus that property rights allocations are highly effective tools for long-term conservation, see David A. Dana, Overcoming the Tragedy of the Commons: Lessons Learned from the Reauthorization of the Magnuson Act, 24 ECOL L Q 833 (1997). For a discussion of the evolution of the near consensus in favor of privatization of fisheries, see Harry N. Scheiber \& Christopher
} 
how the court could go about and justify this task of distribution using the common law concepts that the menu of the law of nuisance provides - that is, interference with a public right, unreasonable interference with use and enjoyment, or first-in-time/comingto-the nuisance.

Climate change is in many ways the fisheries problem, only of a vastly larger geographic dimension. The atmosphere is a commons natural resource that appears to be vulnerable to over-exploitation in the form of greenhouse gas emissions, and many people believe there is a tipping point after which large-scale climactic changes - the equivalent of the failure of the fishing stock - are likely. ${ }^{44}$ There are deep scientific questions as to exactly how much we must reduce emissions to avoid climate change, if it avoidable at all (and some believe it is not). And there are deep ethical - for many, religious -- questions as to how much we should try to avoid climate change, and how much we should instead simply try to adapt to it. ${ }^{45}$ Implicit in these questions are other quandaries, including how much does the current generation owe future generations, how much should current consumption yield to preservation of the resource for future generations. ${ }^{46}$ And as with the fisheries, any solution requires an allocation of rights and obligations among many actors, indeed many more actors than in the fisheries example. This all would appear to be beyond what a judge could possibly justify as an application of recognized legal principles.

The plaintiff Attorney Generals in the power plant and automakers cases have relied heavily on two cases from before the era of modern environmental regulation. As already noted, one of these, Tennessee Copper, involved what was essentially not a

J. Carr, From Extended Jurisdiction to Privatization: International Law, Biology and Economics in the Marine Fisheries Debates 1937-1976, 16 BERK J INTL L 10 (1998).

${ }^{44}$ See, e.g., Juliet Eilperin, Debate on Climate Change Shifts to the Issue of Irreparable Change, WASH POST, Jan. 19, 2006, at A1 (explaining that a "'tipping' point scenario has begun to consume many prominent researchers" but also noting that "scientists remain uncertain when such a point might occur").

${ }^{45}$ On the ethical debates, see generally James Garvey, THE EHICS OF CLIMATE CHANGE (2008). The connection between religion and climate change perspectives has gained increasing attention in the press. See, e.g., Brad Knickerbocker, Many Religious Leaders Back Climate Change Action, Christian Science Monitor, Dec. 20, 2007, available at www.csm.com; Jane Lampman, Ethical Questions Add New Twist to Climate Change Debate, Christian Science Monitor, Nov. 9, 2006, available at www.csm.com.

${ }^{46}$ This debate often takes the form of contention over whether predicted future costs of unmitigated climate change should be discounted and, if so, at what rate. Depending on the discount rate one employs the costs of future climate change can seem either enormous or relatively modest in present value terms. See Martin L. Weitzmen, “Just Keep Discounting, But .. “, in DISCOUNTING AND INTERGENERATIONAL EQUITY (Paul R. Portney \& John Weyent, eds. 1999) (explaining that a modest discount rate can make future global warming appear to be virtually costless). There are thoughtful proponents of a range of views. See, e.g., Frank Ackerman \& Lisa Heinzerling, PRICELESS: ON KNOWING TH PRIC OF EVERYTHING AND THE VALUE OF NOTHING 186-87 (2004) (arguing against any discounting); Douglas A. Kysar, Discounting . . on Stilts, 74 U CHI L REV 119 (2007) (arguing that discounting lacks any coherent justification); Cass Sunstein \& Arden Rowell, On Discounting Regulatory Benefits: Risk, Money, and Intergenerational Equity, 74 U CHI L REV 171 (2007) (arguing for discounting while exploring the complexities of selecting an appropriate rate); Louis Kaplow, Discounting Dollars, Discounting Lives, 74 U CHI L REV 119 (2007) (developing a nuanced rationale in support of discounting). 
commons problem but a generator of pollution-victim of pollution binary dispute that occurred around a state border. The other case - Missouri v Illinois ${ }^{47}$ - actually supports the view I have been articulating, namely that the courts are not well-suited to resolving tragedy of commons disputes.

In that case, the Mississippi River around Saint Louis was the commons, and the contributors to the degradation of the commons (in the form of the rendering of the water dangerous for human populations) was the joint product of residents and communities from Chicago in the north to Saint Louis itself in the south. The case is generally read as a judicial rejection of Missouri's tort claim on the ground that Missouri had failed to show that Illinois had caused the harm of increased water-borne disease. ${ }^{48}$ Another way of understanding the holding, however, is that the Court simply refused to take on the task of dividing past and assigning future responsibility for what appeared to be a collective degradation of the commons.

The federal courts - and the Supreme Court in particular - have been involved $n$ common resource management under the rubric of federal common law in one domain suits for equitable apportionment of water rights among the states with respect to interstate streams or rivers. The California state Attorney General in the automaker case cited the equitable apportionment cases as establishing the point that the courts can and should tackle technically difficult interstate disputes, ${ }^{49}$ but the history of equitable apportionment may support precisely the opposite view. Equitable apportionment cases are not nuisance cases: they are guided to an extent by more determinate legal principles than nuisance law provides, namely, the state water law of the states to the disputes. And the scope of the cases as a geographic matter is much more limited than the global warming suits. But the water cases do involve commons resources threatened with excessive or distorting human demands (although not potentially irreversible tipping points, as in climate change or the fisheries example). And as such, the cases may teach us something about the federal courts' capacity as common resource mangers working with common law principles as their tools. What they teach is that common resource management is not readily managed -- and perhaps should not be at all managed -- by the courts.

Equitable apportionment doctrine, as shaped by the Supreme Court, is just that an equitable doctrine that seeks to do fairness to the claims of the competing states and

\footnotetext{
${ }^{47} 200$ U.S. 496 (1906).

${ }^{48}$ See Thomas W. Merrill, Golden Rules for Transboundary Pollution, 46 DUKE L J 931, 999 (1997) ("the conventional view of the holding of Missouri v. Illinois" is that " the plaintiff state must prove by clear and convincing evidence that it has suffered actual injury”); New York v. New Jersey, 256 U.S. 296, 309 (1921) (citing Missouri $v$ Illinois for the proposition that "the threatened invasion of rights must be of serious magnitude and it must be established by clear and convincing evidence").

${ }^{49}$ See Appellant's Opening Brief, California v. General Motors Corp. et al, in the United States Court of Appeals for the Ninth Circuit, Case No. 07-16908, at 37 (arguing that the Supreme Court in Nebraska $v$ Wyoming "undert[ook] a detailed and highly technical apportionment of the waters of the North Platte River as between Nebraska, Wyoming and Colorado" and is therefore "apt here").
} 
that broadly encompasses a wide range of factors. The Court does look to the law of the disputing states to determine how each state's law would treat the dispute if the dispute were an intrastate, rather than interstate one. But the water law of some states is itself the highly open-ended beneficial use doctrine, and even when disputes involve states with the more determinative priority-of-appropriation doctrine, the Court has said that priority of appropriation will inform but not decide the allocation. As the Court explained in Nebraska v. Wyoming,

Apportionment calls for the exercise of an informed judgment on a consideration of many factors. ... physical and climactic conditions, the consumptive use of water in the several sections of the river, the character and rate of return flows, the extent of established uses, the availability of water storage, the practical effects of wasteful uses on downstream areas, the damage to upstream areas as compared to the benefits to downstream areas if a limitation is imposed on the former - these are all relevant factors. They are merely an illustrative, not an exhaustive catalogue. They indicate the nature of the problem of apportionment of interest which must be made. ${ }^{50}$

As a practical matter, then, equitable apportionment calls on the Court to do balancing of the needs of each of the disputing states, considering both current uses and development and also future uses and development. So while these commons resource disputes regarding water do not raise as many issues as and do not have as great geographic scope as climate/atmosphere disputes, they do call on the court to tackle very difficult, potentially very long-term resource management questions.

Many observers think the Supreme Court has not done a particularly good job when it decides these cases. ${ }^{51}$ Almost all commentators have advocated interstate compacts and Congressional action as an alternative to equitable apportionment by the Court, in large part because of doubts that the Court (or any court) can ever absorb the needed technical information or can take account of ongoing changes in facts on the ground (and in the water, so to speak). The Supreme Court, moreover, seems to share this view: the Court has explained that it decides these cases only because better means of resolving the disputes have not been employed. Judicial resolution of water disputes is,

\footnotetext{
50325 U.S. at 589 (1945), modified, 345 U.S. 981 (1953). Since Nebraska, the Court has added conservation efforts and conservation capacity as another relevant factor in equitable apportionment.

${ }^{51}$ As Benjamin Snowden summarizes the criticisms, "Despite its frequent use, Supreme Court adjudication of water controversies has been criticized on a number of grounds. A common criticism is that the factual and technical complexity of water disputes puts them outside the Court's institutional competence .... A related criticism of judicial apportionment focuses on the cost and delay of litigation. . . . Far more trenchant criticisms of litigation focuses on the uncertainties associated with it. There are at least two sources of this uncertainty: the vagueness of the equitable apportionment doctrine itself, and the impermanence of adjudicated 'solutions.”' Benjamin L. Snowden, Bargaining in the Shadow of Uncertainty: Understanding the Failure of the ACF and ACT Compacts, 12 NYU Envtl L J 134, 154 (2005). See also Joseph L Sax et al, LEGAL CONTROL OF WATER RESOURCES 137, 750 (2d ed 1991); Carl Erhardt, The Battle Over the "Hooch": The Federal-Interstate Water Compact and the Resolution of Rights in the Chattahoochee River, 11 STAN ENVTL L J 200, 213 (1992).
} 
according to the Court itself, an "awkward and unsatisfactory" approach that is much inferior to interstate compacts reached by "by conference and mutual concession on the part of representatives of the states ...."52 And more recently, the Court has imposed a very high threshold for granting judicial review of interstate water disputes: review will be granted only upon "clear and convincing" evidence that the complaining state faces imminent harm ${ }^{53}$; this standard for review comes close to closing the Court to states seeking a resolution of competing demands on limited water resources. Taken as a whole, then, the story of the equitable apportionment story is not supportive of the extension of nuisance law to address management of the atmospheric commons (which, again, is a vastly more daunting commons problem than usage of interstate waters).

Finally, the one case that recently did call on the federal courts (and the Supreme Court in particular) to apply nuisance (as opposed to federal common law of equitable apportionment) law to an interstate commons dispute highlights judicial misgivings about an ostensibly non-political, non-administrative branch of government taking on such a task. In Ohio v. Wyandotte Chemicals Corp. ${ }^{54}$ the State of Ohio moved for permission to file a complaint alleging that the dumping of mercury into Lake Erie by Michigan and Canada-based facilities in the states bordering the Lake was causing a public nuisance that should be abated. The Court did hold that it had jurisdiction, distinguishing cases that were too "political" for the Court to exercise jurisdiction. ${ }^{55}$ However, the Court went on to explain that the novel, difficult scientific issues involved in the dispute, coupled with the need (if review were granted) to allocate responsibility among multiple actors, was more than the Court realistically could do or at least do well:

We already know, just from what has been placed before us on this motion, that Lake Erie suffers from several sources of pollution other than mercury; that the scientific conclusion that mercury is a serious water pollutant is a novel one; that whether and to what extent the existence of mercury in natural waters can safely or reasonably be tolerated is a question for which there is no firm answer . . . . Indeed, Ohio is raising factual questions that are essentially ones of first impression to the scientists. ... . Other factual complexities abound. For example, the Department of Interior has stated that eight American companies are discharging, or have discharged, mercury into Lake Mercury or its tributaries.

\footnotetext{
52 See Dyer v. Sims, 341 U.S. 22, 27 (1951).

53 See Colorado v New Mexico, 467 U.S. 310 (1984) (establishing the "clear and convincing evidence" standard for equitable apportionment claims); see also George William Sherk, Equitable Apportionment After Vermejo: The Demise of a Doctrine, 29 NAT. RESOURCES J 565, 577 (1989) (arguing that the standard adopted in Colorado v. New Mexico reflects the Court's "displeasure with its role in resolving interstate water conflicts.”).

54401 U.S. 493 (1971).

${ }^{55}$ Id. at 495; see also Mathhew F. Pawa, Global Warming: The Ultimate Public Nuisance, in Clifford Rechtschaffen \& Denise Antolini, eds., CREATIVE COMMON LAW STRATEGIES FOR PROTECTING THE ENVIRONMENT (ELI 2007), at 145 (arguing that the Ohio $v$ Wyandotte is "binding precedent" to the effect that global warming is justiciable issue).
} 
We would, then, need to assess the business practices and relative culpability of each to frame appropriate relief . . . ${ }^{56}$

Perhaps, though, the problem is that the courts have not struck on a good approach that would allow them to do well in managing commons resource management disputes across state lines, even perhaps a dispute of the immense proportions of climate change. The next two sections consider two proposed approaches suggested by leading academics - full-fledged cost-benefit balancing in pursuit of an explicit goal of “efficiency” and application of a reciprocity-focused Golden Rules standard. Neither approach, however, makes judicial embrace of climate change case seem any more like a first-best solution.

\section{(a) The Inapplicability of A Cost-Benefit Balancing Approach}

In a recent paper, Keith Hylton argues that cost-benefit balancing is how courts generally should decide public nuisance cases, and should decide in particular whether a greenhouse gas-emitting use or activity should be deemed a nuisance. Hylton's formulation has a long lineage in the "law and economics" scholarship of torts, but he may be the first to argue that a cost-benefit-driven mode of public nuisance law should be extended to disputes over greenhouse gas emissions. He argues that reductions in greenhouse gas emissions should be ordered by a court - or even that a regulatory abatement order should be enforced by a court -- only when "the social benefits of the standard are greater than the social costs. In other words, cost-benefit analysis should apply to the enforcement of all command-and-control standards." 57

Of course, balancing social costs versus social benefits is never uncontroversial, as the previous discussion of equitable apportionment of water rights by the Supreme Court already has suggested. When courts have explicitly done cost-benefit balancing in the course of trying to decide whether to find and/or enjoin a nuisance, they have at times struck balances that seem highly contestable at best. In the famous Boomer ${ }^{58}$ case, the New York court refused to enjoin a cement factory's operations on the ground that the direct economic costs to the cement factory and the indirect economic costs (in lost employment and taxes and so on) of shutting the factory down would exceed the loss in property values to the neighbors that resulted from the soot and noise from the cement factory. (The court, perhaps gullibly, accepted the factory's argument that it could not abate pollution and remain in operation.) But the court did not try to assess many aspects of the "cost" of the cement operations that might have made the cost assessment and hence balancing more difficult; for example, no attention was paid to possible health and emotional costs from the cement dust or the long-term economic costs to the community from the cumulative physical damage to a large area from pollution and the consequent

\footnotetext{
56401 U.S. 493, 503-04 (1971).

${ }^{57}$ Keith N. Hylton, The Economic Theory of Nuisance Law and Implications for Environmental Regulation, June 2007, at 14 (forthcoming CASE WES L REV 2008).

${ }^{58}$ Boomer v. Atlantic Cement Co., 257 NE 2d 870 (NY 1970).
} 
long-term inability to attract new residents and businesses. Depending on what one wants to include in the cost and benefit categories for Boomer and like cases, and the evidence and methods one allows for in the assessment of the kinds of costs and benefits to be included, shutting the factory (or other use) or leaving it open can be defended as an efficient -- as yielding greater net benefits greater than costs -- or not. Boomer and like cases - the social-utility-balancing approach to the law of nuisance generally -- prioritizes judges personal conceptions of what costs and benefits count rather than any neutral principle regarding “cost” or "benefit." 59

In the Boomer-type situation, however, it is at least plausible for the court to assume that the shutting down of the plant, if that really would result from an injunction, would have some clear immediate economic costs in the form of lost equipment and other capital investments by the plant owners and some clear immediate benefits, in the form of less soot in neighbors' homes and gardens. But when we move to the climate change/global warming context, it is hard to say anything certain about the social costs of greenhouse gas emissions from the public nuisance defendants that the public nuisance plaintiffs seek to have abated. The reason is this: the environmental costs of greenhouse gas emissions -and hence the benefit of any ordered reduction in emissions - necessarily depends on the conduct and behavior and decisions of hundreds and thousands of actors outside the lawsuit. Depending on what those actors do, a ten thousand ton ordered reduction in $\mathrm{CO} 2$ could yield great environmental benefits or none at all, or some benefits, with the significance of the "some” being next to impossible to guess.

To see this point most clearly, we can indulge a number of unrealistic assumptions that would make the life of the common law judge easier. First we can assume that for present purposes all that matter is US emissions. We can also assume that it is possible for the court to identify a certain percentage in reduced US emissions that will significantly reduce the risk of adverse effects from climate change, and that reduction is (let us say) 30 percent. One might hope that armed with these two heroic, unrealistic, wildly-simplifying-matters assumptions, a common law judge then could assess the environmental benefit of reduced emissions from a power plant at issue in a suit before her and then proceed to balance that benefit against the social costs of the abatement. But if the judge were to order a 30 percent reduction in the emissions of the nuisance defendant, then that reduction could have any number of possible effects, depending on what happens outside the confines of the lawsuit. Possible effects include:

- $\quad$ No effects at all: If actors outside the lawsuit maintain or increase their net emissions, then the reduction by the nuisance defendant might be overwhelmed or cancelled, so that its reduction would have no environmental effect. ${ }^{60}$ Conversely, if actors outside the lawsuit reduce

\footnotetext{
${ }^{59}$ For two thoughtful critiques of Boomer and the Boomer approach, see Louise A. Halper, Nuisance, Courts and Markets in the New York Court of Appeal 1850-1915, 54 ALBANY L REV 301 (1990); Jeffery J Rachlinski \& Forest Jourdan, Remedies and the Psychology of Ownership, 51 VAND L REV 1541, 1543 (1998). See also Jesse Dukeminier, PROPERTY (6 ${ }^{\text {th }}$ ed. 2006), at 653-665 (discussing Boomer).

${ }^{60}$ It is even possible that the order requiring reductions in emissions by defendants will encourage nondefendants to increase their emissions. Compare Jason Scott Johnston, Climate Change Hysteria and the
} 
their emissions substantially so that the 30 percent target will be met without the reductions by the nuisance defendant, the incremental benefit of the reductions by the nuisance defendant would be insignificant.

- $\quad$ A huge effect. If we assume again a pivot or tipping put at 30 percent net reduction in emissions and that the reductions by actors outside the lawsuit will fall just sort of the 30 percent net reduction target, then the ordered reductions by the nuisance defendant could be extremely important, making the difference between the target being met or not.

- $\quad$ Some effect over a broad range of possibilities. If actors outside the lawsuit reduce emissions by a substantial amount but not necessarily an amount just sort of the 30 percent target, then the ordered reductions by the nuisance defendant could help the nation meet its target but how much help would be open to a range of estimates or, more honestly, guesses.

Of course, the common law judge could address some of these problems by somehow bringing into the lawsuit all the other actors that substantially contribute greenhouse gas emissions. But given how many actors that would entail, and the legal problems of exercising jurisdiction over such diverse actors as well as the institutional strain of a massive lawsuit, this would not be a realistic option. And even if it were, the judge would have to confront the question of how to allocate rights to greenhouse gas emissions among all the actors in the suit. And how could the judge possibly do that?

Following Hylton's formulation, one might expect that the allocation could be made on the basis of the marginal cost to each of the various actors of a reduction in greenhouse gas emissions. That approach, however, would place unreasonable demands on the judge; she would need to find out and verify the costs of marginal reductions for each actor. Moreover, it is not at all clear that an allocation of the greatest reductions to the actors that can most cheaply reduce emissions would be best from a cost-benefit, efficiency perspective. Hylton himself agues that the social costs of reducing emissions in a poor country in China may be greater than in a rich country like France because the marginal unit of GDP or marginal employment opportunity lost in China costs more hurts more - than in France precisely because China is so much poorer. ${ }^{61}$ But of course, China, like less-wealthy countries generally, has more opportunities for (in absolute terms) lower -cost reduction in greenhouse gas emissions than rich countries like France because existing technology in China is not (generally) now as greenhouse-gas-emissionefficient as it is France. The same logic could be applied within the United States. The marginal cost of reducing emissions in a factory in a depressed area of the Midwest may be lower in absolute terms than the marginal costs of reducing emissions from a hightech facility in Silicon valley, but the socioeconomic consequences of placing the burden

Supreme Court, available on www.ssrn.com, at 4-5 (arguing that unilateral emission reductions by the United States "will likely have the perverse effect of lessening the incentive for latecomers to climate change regulation (such as China) to themselves take costly action to reduce such emissions").

${ }^{61}$ See Hylton, supra note [ ], at 21. 
on the Midwestern facility might well be troubling and hence make the Silicon Valley facility the more "efficient" bearer of the reductions.

In the end, even with balancing costs and benefits as its guidepost, the task of allocating emissions rights and reductions would force upon the court a bewildering array of competing considerations that the court could hardly muddle through. If emission rights are to be allocated along with reduction responsibilities, the legislature and regulatory agencies should shoulder the task, as they did with the allocation of sulfur dioxide rights in the context of the Clean Air Act's acid rain program. ${ }^{62}$ Congress and the Executive no doubt will have great difficulty undertaking this task, but as the political or democratic branches, they at least have more legitimacy in taking on a task that cannot be described honesty as anything but a deeply political, deeply value-laden task.

\section{(b) The Inapplicability of a Golden Rules Test}

Tom Merrill has argued that courts have and should use a Golden Rules approach to resolve transboundary pollution disputes. ${ }^{63}$ His two Golden Rules for each state are do unto other states as you would have them do unto you, and do not ask of other states any more than you ask of your own residents. Applying these rules to the global warming public nuisance suits against power producers, he argues that the Connecticut Attorney General and other plaintiffs should lose because they are asking out-of-state generators to make reductions in greenhouse gas emissions that they (or their state governments, more precisely) are not imposing on power generators within their states. ${ }^{64}$

\footnotetext{
62 The ability of Congress to transcend a deadlock over acid rain provides some reason to hope that differences in regional interest regarding climate change and its effects also can be overcome. Although as Jason Johnston emphasizes, the costs of reducing greenhouse gas emissions may be greater for some states than others, see Johnson, supra note [ ], at 35-38, the Clean Air Act has already addressed an even more pointed disparity in costs across regions in the form of the acid rain amendments of 1990. See generally Paul L. Joskow \& Richard Schmalensee, The Political Economy of Market-Based Environmental Policy: The U.S. Acid Rain Program, 41 J L ECON 37, 80 (1998) (explaining that “[d]uring most of the 1980s, the Midwestern and Appalachian utility and mining elements of this coalition managed to use their control over key congressional leadership positions, combined with presidential opposition to new environmental legislation, to block new acid rain legislation. However, once it became clear that acid rain legislation was likely to be enacted as part of a larger reform of the Clean Air Act, our analysis indicates that this coalition was unable to avoid appreciable control costs by obtaining a disproportionate share of emissions allowances.”).

63 See generally Merrill, supra note [ ]. Merrill defends the Golden Rules approach in part by arguing that it frees the courts from the uncomfortable responsibility of making the various value judgments called for by any cost-benefit approach. In other words, Merrill argues that his approach avoids the kind of criticism I have made with respect to the Hylton approach. See Merrill, supra note 4, at 330-31 ("the golden rules cast the court in a role it should be more comfortable playing. The court is asked to investigate existing legal norms and practices of the contesting parties and their home States in order to discover the most closely applicable rule of decision. In contrast, under . . . [a] cost-benefit model, the court is required to in effect 'legislate' a rule, based on its . . . measurement of costs and benefits.”).

${ }^{64}$ See Merrill, supra note 4, at 332 ("Under the golden rules approach to determine the standard of public nuisance liability, it seems relatively clear that the AGs would lose. . . . Connecticut and the other plaintiff States are ... guilty of asking of other states what they do not ask of their own citizens”).

);
} 
The appeal of the Golden Rules approach would seem to be, in part, that it removes judges from making difficult values judgments as to what kinds of polluting or non-polluting activities have more social utility or otherwise should take priority; rather, the courts can simply ask states to ask no more of other states than they are already doing in terms of their own residents and any transboundary emissions they generate. The Golden Rules approach also taps deep intuitions regarding reciprocity.

In the climate change context, however, it is unclear whether invocation of the Golden Rules adds any determinacy at all. The reason this is so is that the "correct" metric for comparing greenhouse gas emissions across borders is highly contestable.

The debates over the Kyoto Protocol and subsequent calls for international emissions accords show why this is so. The United States has argued that any reductions in greenhouse gas emissions going forward should be matched by the same reductions in countries such as China and India. Those countries, however, have argued that the metric for comparison should not be future emissions in absolute terms but rather historical or net emissions, in which case the United States should be making much more dramatic reductions than China or India. Alternatively, China or India have argued that the metric for comparison should not be emissions in absolute terms but rather emissions per person or unit of GDP, in which case (again) the United States would face much bigger reductions than China or India. ${ }^{65}$ On the other hand, because greenhouse gas emissions come not just from fuel combustion but also land clearing and deforestation, the United States can argue for credits for reforestation or (as Russia did in Kyoto negotiations) forest preservation (that is, credit for maintaining and not cutting down its large established forests). ${ }^{66}$

The metric-for-comparison problem is perhaps easier within just the United States, but not much. Should fast growing regions of the country such as the Southwest be allocated more emission rights than other parts of the country? Should the fact that some states have more modern, energy-efficient plants means those states should be required to make lesser reductions than states with plants that have antiquated technology

Harper, supra note [ ] at 686 (arguing that "[t]he 'unclean hands' doctrine is an obstacle to the plaintiffs in the [power plant] lawsuit inasmuch as they are guilty of the same kind of emissions that are the subject of their complaint”).

${ }^{65}$ The literature over whether a "per capita" allocation approach is the just or correct means of distributing - and if so what kind of per capita approach is just - is enormous. There is no consensus among thoughtful commentators. Compare Eric A. Posner \& Cass R. Sunstein, Should Greenhouse Gas Permits Be Allocated on a Per Capita Basis?, March 2008, available on ssrn.com (arguing that considerations of justice do not support per capita allocation) with Michael Grubb et al, Sharing the Burden, in CONFRONTING CLIMATE CHANGE: RISKS, IMPLICATIONS AND RESPONSES 318-319 (Irving M. Mintzer ed). For a good overview of possible per capita approaches, see Daniel Boadansky, INTERNATIONAL CLIMATE CHANGE EFFORTS BEYOND 2012: A SURVEY OF APPROACHES (2004).

${ }^{66}$ See Clare Breidenich et al, The Kyoto Protocol to the United Nations Framework Convention on Climate Change, 92 AM J INTL L 317, 322 (1998) (explaining that accounting for forest or other C02 "sinks" was a problematic part of the Kyoto negotiations, and the agreed-upon accounting does "reward countries that are increasing their forestry sinks, and penalize those whose sinks are decreasing."). 
and hence greater greenhouse gas emissions per unit of power? Should a state's adoption of measures to improve automobile fuel economy (and hence reduce greenhouse gas emissions from cars) and measures to set aside forested areas mean that they need not make as great reduction in power plant emissions as states that have not taken such measures? Invocation of the Golden Rules answers none of these questions. In sum, cost-benefit balancing a la Hylton or Golden Rules a la Merrill might help if courts were to undertake the task of using public nuisance as a means of addressing the problem of climate change, but these approaches would only get them so far.

The bottom line is: Climate change is an extraordinarily hard commons management problem that does not seem to be a task that the courts, in their common law role, are particularly well-positioned to assume. It is a national and international problem of property rights assignment and resource management which should, in a first best world, be addressed by the federal political branches.

\section{STATE LEGISLATION AS A PREFERRED MEANS TO ADDRESS FAILURES IN THE FEDERAL POLITICAL PROCESS}

One might argue that the preceding analysis, even if true, avoids a very important question: where should California and like-minded states turn for help in prompting the federal political branches to take on the question of what to do about greenhouse gas emissions? If the federal government is doing nothing or at least not enough about global warming, and if global warming is a pressing issue that the federal government should be addressing, what can California and like-minded states do if they cannot resort to the courts and common law public nuisance actions?

Moreover, one might ask, why we should worry much about the limitations of the courts using the common law if the courts are to be used simply as an instrument to prod action by the federal political branches? After all, if a common law suit or suits did produce orders requiring large greenhouse gas emission reductions or large damages awards for the costs of such emissions, it is quite possible that industry and business groups that have resisted federal greenhouse gas regulation would reverse course and push for new federal regulation that would override the court decisions and preempt any future ones. Wouldn't that be a good thing, if global warming really is an issue best suited for the federal political branches?

These questions are important ones, but the answer to all of them is not that the courts should proceed with the common law actions as part of a coordinated effort with certain state AGs to prompt change within the federal political branches. This Part explores some of the problems with an agenda-prompting or agenda-setting rationale for public nuisance global warming suits. It then argues that if the courts are to have a role in prompting federal Executive and Congressional consideration of the problem of global warming, they should do so through their engagement with state legislative attempts to address the problem of greenhouse gas emissions. And the substance of that role should be more passive than active, that is, the courts should err on the side of rejecting federal 
preemption and dormant commerce clause challenges by regulated businesses to such state legislation and regulation.

\section{(a) Agenda-Prompting by the Courts and Global Warming}

One problem with a federal-agenda-prompting rationale is that it assumes that there is some problem in the federal political process that the courts must try to correct by (along with the state AGs) altering the federal political environment. However, it is not obvious that the federal political branches have not taken more action than they have with respect to global warming because of distortions in the federal political process (such as excessive influence by concentrated business groups at the expense of more diffuse "public" interests ${ }^{67}$ or politicians' self-interest in avoiding difficult issues in favor of easy ones such as seeking "pork" for their districts). One can plausibly argue that Congress and the Executive have paid the attention that seems "correct" to climate change in that the relatively limited federal action to date simply reflects the scientific and technical and diplomatic difficulties associated with climate change as a problem, and the wide range of opinions across the country (and the world) as to how much resources to devote to the problem. In this view, any absence of decisive federal action to date does not reflect a federal process failure in any meaningful respect, but rather the inherent difficulty of the climate change problem. Further at least after Massachusetts $v$ EPA, it seems reasonable to predict that we will observe more federal action on global warming in the near term, although how much more is certainly very hard to say. ${ }^{68}$

\footnotetext{
${ }^{67}$ Climate change is, in many ways, the prototypical issue for which the Mancur Olson framework would suggest disproportionate influence - including agenda-setting influence - of opponents of significant federal engagement. See Mancur Olson, Jr., THE LOGIC OF COLLECTIVE ACTION: PUBLIC GOODS AND THE THEORY OF GROUPS (1971) (explaining why concentrated groups' preferences tend to be reflected more heavily than would be the case under a pure preference aggregation model in the provision of public goods). For most Americans - millions of them -- climate change may be an issue of modest if real concern. By contrast, there are individual actors - large corporations - with huge financial resources and a strong stake in avoiding rules, regulations or requirements that discourage the use of coal or oil and/or increase the cost of power generation and/or automobiles. Exxon and GM are just two such corporations. Moreover, the industries that are most vulnerable to the costs of climate-change regulation are significantly concentrated in certain states, and in those states employees and communities that depend on those industries form a concentrated group that may resist regulation. In the American political context, geographic concentration of an interest group within a state or few states confers particular advantages because the composition of the Senate makes the group or groups that dominate each particular state relevant, and the rules and culture of the Senate gives the Senators from a single state or a few potentially great power to keep issues off the legislative agenda or to at least slow their consideration. The geographically-oriented system of representation that we have may be part of the brilliance of the original design of Our Constitution, but it can foster results that certainly seem notably "undemocratic" from the perspective of a majoritarian conception of democracy. See Sanford Levinson, OUR UNDEMOCRATIC CONSTITUTION 9 (2006) (arguing for a new Constitutional Convention to address the undemocratic aspects of our current constitution).

${ }^{68}$ Massachusetts $v$ EPA only establishes that the federal EPA needs to assess the role of greenhouse gas emissions as pollutants under the federal Clean Air Act. The actual regulatory outcomes of that assessment, however, were not dictated by the Supreme Court. At the nation-state level, the United States still has not passed comprehensive climate change legislation or entered into any binding international commitments to reduce greenhouse as emissions. At the moment, as the State of California Attorney General has argued, federal laws and programs "touch[]" upon greenhouse gas emission issues but there is
} 
Moreover, even if a very plausible argument can be made that there has been and will continue to be a failure in federal politics regarding global warming, it is far from clear that the courts should use the common law to try to force a correction of that failure. The political-failure-correction rationale for judicial exercises of jurisdiction is normatively problematic as a general matter, even if it may have some appeal in the climate change context. Given how easily it would be for a court to convince itself that almost any issue has received too little federal attention as a result of a federal political process failure, this rationale would seem to have no stopping point in actual practice. And almost everyone would agree that, at least outside the domain of individual constitutional rights, basic democratic commitments mean the courts should err on the side of leaving politics, for all its many imperfections, to the voters and the politicians.

Finally, it is not assured that common law orders and judgments would rapidly produce new federal laws and hence be supplanted. A sweeping common law order directed at power plants might not be preempted by federal legislation for some time ${ }^{69}$ and, even assuming eventual preemption, the order itself almost certainly would have shaped senses of entitlements and responsibilities that will influence the substance of any new federal regulation. And even if the new federal regulation is not influenced or framed by the court order, the uncertainty and transition costs created by the shift from common law to federal regulation is bound to entail very large economic costs.

\section{(b). The Greater Democratic Legitimacy and Accountability of State Legislation}

State legislation is perhaps the best answer to the concern that the states that bear the greatest potential costs from climate change need some way to capture the attention of the federal political branches. By enacting state legislation that imposes strict greenhouse gas emissions requirements on processes and products used within their states, these states can alter the federal political landscape in a way that promotes more federal attention and concrete action. Compared to common law public nuisance suits, such state legislation entails a greater degree of democratic legitimacy and accountability. State legislation also carries a lesser risk of producing highly parochial yet far-reaching greenhouse gas emissions solutions that undervalue or ignore the interests of certain regions of the country.

Federal courts (or even state courts) are not thought to necessarily reflect the values and views of "The People" as a whole or even the electorate in the state where the

not yet anything approaching a "'comprehensive scheme' speaking directly to that particular issue .....” Appellant's Opening Brief, California v. General Motors Corp. et al, in the United States Court of Appeals for the Ninth Circuit, Case No. 07-16908, at 63.

69 There are multiple veto points in the legislative process in Congress long before any vote of the full Congress, so it cannot simply be assumed that Congress will correct all judicial missteps, even if a Congressional majority would, if asked, vote to do so. See generally Einer Elhaughe, Preferenceestimating Statutory Default Rules, 102 COLUM L REV 2027, 2084, 2105 (2002) (arguing that an enacting Congress would want courts to estimate the current or sitting Congress' preferences in cases where inertia predictably would prevent the current or sitting Congress from expressing those preferences in new legislation). 
court is located. The state AGs who bring public nuisance suits, however, are elected and thus might be thought to have some democratic legitimacy and confer that legitimacy on the lawsuits. By definition, however, state AGs must be presumed to have a parochial vision: they are elected only by voters in a single state ${ }^{70}$ and presumably lack an incentive or capacity to survey and understand national let alone international sentiments. Morever, it is debatable how well State AGs reflect the sentiments of the electorate even of the states from which they hail. When a state enacts a law, typically there must be majority support in the legislature and support from the Governor or, if the bill is passed over a veto, overwhelming legislative support. A state AG's initiation of a lawsuit, by contrast, does not even necessarily require support of the Governor: indeed, a Governor may well be able to do nothing to stop a state AG from initiating or continuing to litigate a suit. $^{71}$

With a state statute, in contrast to an AG public nuisance suit, there is not only greater ex ante assurance that the state effort has strong political support within the state, but also greater democratic accountability ex post if it does not. AG-initiated suits do not have to stake out a clear vision and commitment as to specific measures to be undertaken, inasmuch as the prayer for relief in a complaint is typically open-ended. To the extent that the court issues an order with very specific provisions, it is the court - and not the AG - that is likely to be held responsible for the contents of that order and the results. By contrast, each legislator who votes for a bill and the Governor who signs a bill is on record as having voted or signed something that can be read, evaluated and debated. The level of democratic accountability - the potential for calling the politician to task for doing or supporting something that some people within the relevant state actually may object to - is less when a lawsuit is filed in a court and a judge in effect takes control than when a bill is debated, voted upon, and signed.

The California car legislation and regulations that are currently the subject of federal litigation provide a good example of how state legislatures can address through new laws some of the same aspects of climate change that otherwise could be addressed by a state-AG public nuisance suit. The California car regulations would require automobiles sold and used in California to produce substantially lower levels of

\footnotetext{
${ }^{70}$ Forty three of the state AGS are elected; five are appointed by the state's governor; and one each is selected by the state legislature and the state supreme court. See Jason Lynch, Federalism, Separation of Powers, and the Role of State Attorneys General in Multistate Litigation, 101 COLUM L REV 1998, 2006 (2001).

${ }^{71}$ For a useful discussion of the very broad discretion enjoyed by State AGs, see Timothy Meyer, Federalism and Accountability: State Attorneys General, Regulator Litigation, and the New Federalism, 95 CAL L REV 885, 892-95 (2007). In some cases the courts have been drawn into the relationship between a State AG and a Governor, and where they have, they have generally come down on the side of the AG's right to be free from gubernatorial interference. See William Marshall, Break up the Presidency? Governors, State Attorneys General, and Lessons from a Divided Executive, 115 YALE L J 2446, 2453-68 (2006). In a study of state AG's decision whether or not to join suits against tobacco companies, the Governor's political party affiliation (and hence presumably ideology) has no significant, measurable effect on the decision of the state AGS. See Rorie L. Spill, Michael J. Licari \& Leonard Ray, Taking on Tobacco: Entrepreneurship and the Tobacco Litigation, 54 POL RE Q 605, 616 (2001).
} 
greenhouse gasses in the relatively near future. ${ }^{72}$ More than a dozen states have followed California's lead and adopted the same regulations for cars to be sold and used in their states. $^{73}$ These new state laws - even though their legality under federal law is in dispute - may have already convinced the automakers to be more supportive of stricter federal fuel economy standards as part of an effort on their part to avoid or reduce the momentum behind new state requirements. ${ }^{74}$

The California car regulations also highlight another advantage of state legislation, as compared to public nuisance suits - namely, that state legislation invariably imposes some in-state costs, because it is necessarily is directed at processes within or products sold or used within the legislating state. By contrast one can imagine orders emerging from AG suits that impose no obvious in-state costs because the suits are directed at defendants that engage in processes that take place entirely outside the suing state. In-state costs are important because they provide some check on - some discipline for - state political actors, and thus may screen out some proposals or approaches that would produce reductions in greenhouse gas emissions only at tremendous, disproportionate costs to the nation as a whole.

For example, strict greenhouse gas emissions regulations on in-state electricity generators imposes costs on the producers and consumers within the state. State greenhouse gas emissions regulations for cars impose costs on in-state car dealers and purchasers, even if large costs are born by the out-of-state car manufacturers (and perhaps by consumers in other states, if the manufacturers change the design for their cars for the national market as a whole in response to state legislation). By contrast, a public nuisance suit against out-of-state power plant producers probably would not appreciably increase the costs of power within the states bringing suit.

State greenhouse gas emission legislation is vulnerable to two major legal challenges - a challenge that its is impliedly preempted by federal law, and a challenge that the legislation impedes free trade and thus violates the dormant commerce clause. The courts can facilitate state efforts to prompt federal action regarding climate change by adopting a doctrinal approach to the preemption and dormant commerce clause challenges that makes such challenges unlikely to succeed, except in clear cases of state overreaching.

\footnotetext{
${ }^{72}$ See CAL. CODE REGS. Tit. Sec 1961.1 (2007) (California emissions regulations adopted pursuant to Cal. Health \& Safety Code Sec. 43018.5).

${ }^{73}$ See Clean Cars Campaign, about the Clean Cars Campaign, http://www.cleancarscampaign.org. See also David A. Dana, Democratizing Preemption, 102 NW L REV --- (2008) (arguing that the weight of democratic support in the states for a nonfederal alternative to the federal fuel economy standards should be a factor in favor of a judicial finding that the federal standard lacks preemptive effect); Ann E. Carlson, Federalism, Preemption, and Greenhouse Gas Emissions, 37 UC DAVIS L REV 281 (2003) (reviewing the context for and history of the California regulations).

${ }^{74}$ See John M. Broder, Federal Judge Upholds Law on Emissions in California, NY TIMES, Dec. 13, 2007, at A32 (suggesting that the industry may be supporting increased federal fuel economy standards in response to the California regulations).
} 
With respect to the federal preemption challenge, such a doctrinal approach would have two elements. First, the courts would apply a heightened ripeness standard for preemption challenges, whereby preemption challenges are not deemed ripe until the particular effects of the state legislation are known. ${ }^{75}$ Such a heightened standard would be consistent with the approach the courts have adopted in other settings implicating federalism concerns, and would give the states the time they need to demonstrate the breadth of support for new or stricter regulation than the current federal standard. Second, once a preemption challenge is ripe, the courts would apply a robust presumption against preemption, whereby an implied Congressional intent to preempt will not be recognized absent some specific, real conflict between federal programs and the challenged state legislation. ${ }^{76}$ The federal district court decision in Vermont rejecting the preemption challenge to the California car regulations is much in this spirit of this suggested approach: the court there held the challengers to a high standard of factual proof that compliance with the California regulations necessarily would require manufacturers to exceed federal fuel economy standards under the Energy Policy Conservation Act, and then found that such a factual showing had not been made and that the state regulations therefore were not preempted. ${ }^{77}$

With respect to the dormant commerce challenge, the suggested approach would build on one strain in the case law that largely confines the dormant commerce clause prohibition on state legislation to legislation that facially discriminates between in- and out-f-state produces or to legislation that is facially neutral but clearly driven by protectionist concerns for in-state producers. There is an alternative strand of case law regarding the dormant commerce clause, according to which the clause establishes an open-ended balancing test designed to remove inefficient barriers to trade even when such barriers are not or not even suspected to be motivated by origin-of-product discrimination or protectionism. A court hearing a dormant commerce clause challenge to facially neutral state greenhouse gas emissions regulations would have sufficient doctrinal support with which to reject such a challenge absent some evidence that

\footnotetext{
${ }^{75}$ Some case law suggests that the ripeness standard for preemption challenges is lower or less demanding than that for ordinary cases or for other sorts of cases implicating federalism concerns. See, e.g., Pacific gas \& Electric Co. v. State Energy Resources Conservation \& Development Commission, 461 US 190, 201 (1982) (suggesting that that federal preemption issues are "predominantly legal" and hence ripe for review before the full development of a factual record regarding the challenged state regulation or administrative process). For a description of that case law and an argument for a heightened ripeness standard for preemption challenges, see Dana, supra note, at [ ].

${ }^{76}$ There are many academic advocates for this general approach, see, e.g., Roderick M. Hills, Against Preemption: How Federalism Can Improve the National Political Process, 82 NYU L REV 1, 34-35 (2007) and Caleb Nelson, Preemption, 86 VA L REV 225 (2000), but certainly no explicit judicial acceptance of it by the courts. The case law on federal preemption is characterized by a reliance on formalisms that clouds the absence of any singular, coherent approach by the courts. See Thomas W. Merrill, Preemption in Environmental Law: Formalism, Federalism Theory, and Default Rules, in FEDERAL PREEMPTION: STATE'S POWERS, NATIONAL INTERESTS 166, 166 (Richard A. Epstein \& Michael S. Greve, eds., 2007) (describing “the very formality" of the case law); see also Dana, supra note [ ], at [ ] (describing the inconsistencies in the federal preemption case law).

${ }^{77}$ See Opinion and Order, Green Mountain Chrysler et al v. Crombie, Case No. 2:05-cv-302 (D. Vt.), Sept.et 12, 2007, available at www.vtd.uscourst.gov.
} 
reducing greenhouse gas emissions was merely a pretext for a legislative effort to advance some in-state producer's economic interest. ${ }^{78}$

\section{CONCLUSION}

The courts using the common law method of case-by-case adjudication may have institutional advantages over the more political branches, such as perhaps more freedom from interest group capture and more flexibility to tailor decisions to local conditions. Any such advantages, however, are more than offset by the disadvantages of relying on the courts in common resource management in general and in the management of the global atmospheric commons in particular. The courts are best able to serve a useful function resolving climate-related disputes once the political branches have acted by establishing a policy framework and working through the daunting task of allocating property or quasi-property rights in greenhouse gas emissions. In the meantime, states do have a state legislative alternative that is preferable to common law suits, and that federal courts can facilitate without any dramatic innovations in federal preemption or dormant commerce clause doctrine.

\footnotetext{
${ }^{78}$ For analyses of the possible dormant commerce clause problems raised by state greenhouse gas emissions regulations, see Peter Carl Nordberg, Excuse Me, Sir, But Your Climate's On Fire: California's S.B. 1368 and the Dormant Commerce Clause, 82 NOTRE DAME L REV 2067 (2007) ; Donald R. Hodas, State Law Responses to Global Warming: Is It Constitutional to Think Globally and Act Locally?, 21 PACE ENVT L REV 53 (2003).
} 